\title{
POLLITIKK
}

\section{Når alt blir personlig. Trump i internasjonal politikk}

\author{
Vårin Alme \\ AmerikanskPolitikk.no
}

\begin{abstract}
Sammendrag
Denne spalten tar for seg betydningen av personligheten til USAs 45. og sittende president, Donald Trump. Argumentet som fremmes, er at Trumps personlighet, dog mangefasettert, gjennomsyres av særlig ett karaktertrekk, nemlig at han gjør alt - og tar alt - personlig. Dette påvirker internasjonale relasjoner: Med Trump som president blir internasjonal politikk personliggjort. Og med dette følger særlig tre ting: en forskyvning i internasjonale relasjoner, uforutsigbarhet og infantilisme. I spalten forsøker jeg å vise hvordan disse trendene utarter seg, og med det for øyet bruker jeg G7-møtet i 2018 som talende eksempel.
\end{abstract}

Nøkkelord: personlighet • Nato, G7 • handelspolitikk • sikkerhetspolitikk

Da 70-tallets feminister adopterte slagordet the personal is political, var det realpolitisk tankegods de raljerte mot. Realister som Hans Morgenthau hadde operert med tanken om at politikk ikke skal være personlig og at en statsleder nødvendigvis må anta to roller - én som statsleder og én som privatperson - og skille strengt mellom disse. Denne tanken har vært et grunnprinsipp for internasjonal politikk. Mens feministenes poeng var at politikk griper inn i den private sfæren og at et vanntett skott mellom det politiske og det personlige er umulig, var nok ikke hensikten å skrote skillet fullstendig.

I denne kronikken argumenterer jeg for at det nettopp er dette som har skjedd, og det i stor grad som konsekvens av den amerikanske presidentens personlighet og politiske stil. Trumps personlige orientering bidrar til å utviske skillet mellom privat

\footnotetext{
^Kontaktinformasjon: Vårin Alme, e-post: varinalme@gmail.com

(C)2018 Vårin Alme. This is an Open Access article distributed under the terms of the Creative Commons Attribution 4.0 International License (http://creativecommons.org/licenses/by/4.0/), allowing third parties to copy and redistribute the material in any medium or format and to remix, transform, and build upon the material for any purpose, even commercially, provided the original work is properly cited and states its license.

Citation: Värin Alme (2018). Når alt blir personlig. Trump i internasjonal politikk, 76: 241-249. http://dx. doi.org/10.23865/ intpol.v76.1436
} 


\section{Vårin Alme}

og offentlig, individ og stat og nasjonal og internasjonal politikk - i klart brudd med realpolitiske formaninger. Samtidig er han på andre områder en tydelig realpolitiker. I denne paradoksale kombinasjonen ligger nøkkelen til å forstå Donald Trumps personlighet og dens innvirkning på internasjonal politikk.

\section{Donald Trumps personlighet}

Når vi - eller i alle fall mange av oss - tenker at Donald Trump utgjør et brudd med USAs tradisjonelle linje, er det ikke ene og alene på grunn av politikken han foreslår. Det er også på grunn av hvem han er, hvordan han ter seg og hva han representerer. Dermed blir det betimelig å diskutere nettopp dette. Hvem er Donald Trump som politisk leder?

Visse ting tvinger seg frem umiddelbart. De er blitt utesket av kommentatorer og forskere, også her i Internasjonal Politikk. Hilde Restad (2017) har skrevet overbevisende om Trumps økonomiske orientering, som hun mener er uttrykk for en nasjonalistisk-proteksjonistisk utenrikspolitisk ideologi. Anders Romarheim (2017) har kalt Trump en bilateralist som søker dominans over andre stater gjennom sammensmelting av handel og sikkerhet. Det er lett å finne empirisk støtte for disse tolkningene. Gjennom handling og ord uttrykker Trump nasjonalisme, proteksjonisme, et fokus på det økonomiske aspektet - også i sikkerhetspolitikken - og en klar forkjærlighet for bilaterale fremfor multilaterale settinger.

På disse punktene fremstår Trump som en realpolitiker. Han er pragmatisk og forretningsorientert, og bryr seg tilsynelatende lite om verdier, normer, tradisjoner, menneskerettigheter og (inter)nasjonal lov. Denne innstillingen har kommet til uttrykk ved utallige anledninger. Vi kan trekke frem hans gjentatte påstand om at amerikanske styrker skulle ha tatt Iraks olje før de trakk seg ut av landet (Meet the Press 2015). Eller at han unnskyldte Kina for det han tidligere hadde kalt manipulering av økonomien: «I don't blame China. After all, who can blame a country for being able to take advantage of another country to the benefit of its citizens?» Dette er klassisk realpolitikk.

Trumps fokus på økonomisk og materiell vinning ${ }^{1}$ henger sammen med hans forhandlingsfokus. For ham ligger ingenting fast. Snarere er det mulig å forhandle og reforhandle alt, bestandig. Dermed er uforutsigbarhet, for Trump, ikke kun et middel, men et mål og et gode i seg selv - i internasjonal politikk så vel som i privat virksomhet (Alme 2017a, Romarheim 2017).

Et trekk som imidlertid gjennomsyrer alt dette andre, er at Donald Trump tar alt - og anser alt som - personlig. Dette er tydelig i måten han opptrer på samme vis i alle sine geskjefter; han snakker på samme måte og om de samme tingene om han driver et eiendomsfirma, deltar i et realityprogram, står i en nasjonal valgkampdebatt,

\footnotetext{
${ }^{1}$ Trump viser en åpen beundring for handling over ord og for det faste over det myke. I hans vokabular henvises det ofte til målinger, tall, penger, militære styrker og gevinst - alt det som er hardt, håndfast og målbart.
} 
taler som USAs president eller holder en pressekonferanse med en annen statsleder. Denne udiskriminerende formen forteller oss noe grunnleggende om Trumps personlighet - nemlig at hans tilnærming til alt han befatter seg med er personlig.

I politikken har dette særlig vært påfallende. Her har vi gjentatte ganger sett hvordan Trump visker ut skillene mellom staten og seg selv og mellom det offentlige og private. At han, i landsmøtetalen, sa «I alone can fix it», er ett eksempel. Andre eksempler er kommentarer som at han konsulterer seg selv i utenrikspolitiske spørsmål, da han har gode instinkter. Eller mer nylige uttalelser, som at toppmøtet med Nord-Korea ikke handler om forberedelse, men holdning: «Just my touch, my feel. It's what I do». Eller at han ikke fullstendig distanserer seg fra egne businessinteresser og lar familiemedlemmer som Ivanka Trump fungere som sin stedfortreder (Stone 2017). Eller følgende uttalelse til Fox News: "The one that matters is me. I'm the only one that matters. Because (...) that's what the policy is going to be" (Nazaryan 2017, Mitchell 2018, Collins 2016, Lockie 2018). Alt i alt viser dette en systematisk personliggjøring av politikken.

Så skal det sies at det slett ikke er uvanlig at politikere bruker sin egen person og sin egen personlighet for å mobilisere støtte. President Barack Obama bygget eksempelvis sin valgkamp og sitt politiske budskap på egen biografi og historie, og ikke minst på karisma og taleevne. Politikere som Bill Clinton og Bernie Sanders skapte politiske bevegelser rundt det de ga uttrykk for personlig å representere: endring, og endring til det bedre. På lignende vis har Donald Trump forankret sin politikk og sin politiske stil i egen personlighet og egen merkevare. Hans erfaring som forretningsmann, forhandler og leder er blitt brukt flittig her (Steinhovden 2018: 136-139). Det samme er merkevaren som en vellykket, sterk og kompromissløs «fighter» - som underbygges av en karisma som fascinerer både motstandere og støttespillere og en politisk retorikk som sjokkerer, splitter ${ }^{2}$ og skaper oppmerksomhet. Merkevaren forsterkes av direktekommunikasjon med velgerne, enten på Twitter eller på valgmøter - som holdes jevnlig, også utenom valgtider.

Mens Trumps stil, fremferd og kommunikasjonsform står uten historisk sidestykke, er han altså ikke alene i å bruke sin personlighet i politikken. Der han skiller seg fra denne tradisjonen, er ved å gå enda lenger: ved å giøre, anse og ta alt personlig. Dette representerer brudd i alle ledd. Som vi så innledningsvis, står det $\mathrm{i}$ diametral motsetning til realismens idé om å holde det personlige og det politiske atskilt. I internasjonal politikk er det blitt lagt til grunn at statlige ledere, om de så er folkevalgte eller ikke, handler ut fra det de anser som nasjonens interesse. Dette er noe av det som har muliggiort forutsigbarhet i den internasjonale politikken.

Med Trump blir denne antakelsen utfordret. Her forlater han altså realpolitikken. For selv om det ikke er uvanlig for realpolitiske ledere å knytte sin person til

\footnotetext{
${ }^{2}$ Trump brukte splittende retorikk i sin valgkamp. Det ville imidlertid ikke ha vært så effektivt om ikke USA allerede var sterkt polarisert. Splittelsen ble imidlertid tydeliggiort - og kanskje også sementert - gjennom Trumps fremferd (Steinhovden 2018: 149).
} 


\section{Vårin Alme}

politikk og stat (Hill \& Gaddy 2013, Applebaum 2013), er det, i det minste i vår del av verden, ytterst uvanlig å viske ut skillene mellom det personlige og det offentlige. Konsekvensen er nemlig at det sås tvil om hva lederens mål virkelig er: å fremme nasjonen eller å tjene private interesser.

Til slutt går personliggjøringen på akkord med den demokratiske grunntanken om representasjon, der lederens makt springer ut fra folket, og der denne lederen til alle tider holdes til ansvar av solide institusjoner som rettsvesen, politisk opposisjon og en fri presse. Trumps stadige forsøk på å undergrave etablerte amerikanske institusjoner, hyppige avskjedigelser av statsansatte - ofte via Twitter - og krav om lojalitet fra mennesker hvis jobb det er å holde Trump ansvarlig (Comey 2018), er bare noen eksempler på det.

Personliggjøringen er imidlertid ikke et utilsiktet biprodukt av Trumps presidentskap. Det er liten tvil om at personfokuset hjalp ham i valgkampen. Etter valgdagen var en av de gjennomgående teoriene at velgerne hadde tatt ham seriøst, men ikke bokstavelig, mens pressen hadde tatt ham bokstavelig, men ikke seriøst (Zito 2016). Mens poenget her var å forklare hvordan pressen kunne misforstå klimaet i det amerikanske elektoratet, er et minst like interessant poeng at velgerne ikke tok ham bokstavelig. Stemmer dette, betyr det at de overlot politikken til ham og stolte på at han, i kraft av å være den personen han er, kunne hamle opp med et uregjerlig og stagnert system de ikke lenger kunne stole på - at han kunne «shake things up» (McCarthy 2017). Videre kan det forklare hvorfor Trump valgte å konsentrere valgplattformen sin rundt egen person og personlighet: Dette var appellen. Det kan også forklare hvorfor ikke alle republikanske kandidater som går til valg på trumpistisk politikk finner klangbunn hos velgere, selv i områder der Trump vant: De er ikke Donald Trump.

\section{Personliggjøringen av den internasjonale politikken}

Trumps personlighet har allerede fått synlige konsekvenser for internasjonal politikk. Kanskje særlig kan vi identifisere tre slike konsekvenser. Den første er økt ustabilitet. For med en uforutsigbar amerikansk president følger et uforutsigbart og spent internasjonalt klima. Allerede tidlig i Trumps presidentskap så vi hvordan enkle telefonsamtaler mellom statsledere - tradisjonelt ansett som formalia - utviklet seg til diplomatiske småkriser, ikke minst fordi de ble lekket til pressen. Vi så viktige bilaterale møter kansellert over en lav sko og åpen fiendtlighet statsledere imellom. I nyere tid har vi sett Trump veksle mellom kritikk, ros, latterliggjøring og forhandling med Nord-Koreas leder. Vi har sett ham referere til enkelte nasjoner som «shithole countries». Og vi har sett ham kritisere institusjoner som fungerer som bærebjelker i den liberale verdensorden, oppheve (eller true med å oppheve) internasjonale avtaler og iverksette handelstariffer både mot rivaler og allierte (Woodward 2018).

En annen konsekvens av Trumps personlighet er en forskyvning $i$ internasjonale relasjoner. Mønstret vi ser i disse forskyvningene er, i stort, en forsuring av vennskap 
innenfor den liberale verdensorden og en forsoning mellom USA og stater utenfor denne verdensordenen. Dette så vi tendensene til allerede på Trumps første utenlandsreise, der han på én og samme tur inngikk en våpenavtale med Saudi-Arabia, signaliserte at USA ikke vil blande seg inn i hvorvidt andre land opprettholder menneskerettighetene, kritiserte allierte for ikke å oppfylle finansielle krav og unngikk å uttrykke uforbeholden forpliktelse til Alliansepaktens artikkel fem - én for alle og alle for én (Alme 2017c). Det ble også tydelig i kontrasten mellom de vennskapelige møtene hans med Kim Jong-un og Vladimir Putin på den ene siden og de turbulente møtene med G7-landene og Nato på den andre.

Forskyvningen skjer av flere grunner. Fra Trumps ståsted er USAs europeiske allierte snyltere som utnytter USA og som, med mindre de beviselig kan bidra til konkret vinning for USA, er uinteressante forhandlingspartnere - i motsetning til stater som har midler, er villige til å bruke dem og ikke lar verdimessige og moralske skrupler komme i veien for en gunstig avtale. Fra europeiske alliertes ståsted er det derimot nettopp multilateralismen, forutsigbarheten og de delte verdiene som har holdt den vestlige delen av verden relativt fredelig det siste halve århundret. At Trump ønsker seg vekk fra dette grunnfjellet og over på hard realpolitikk, pragmatisk risikovurdering og konkret gevinst - og gjør det på en måte som går på akkord med demokratiets prinsipper - skyver USA i en retning færre og færre allierte kan føle slektskap med.

Med Trumps personlighet følger til slutt en nyvunnet infantilisme i den internasjonale politikken. Mye av det vi assosierer med Trump og hans personlighet, ligger i metodene han bruker, måtene han gjør ting på og, mer spesifikt, hvor langt eller lavt han er villig til å gå. Dette er noe av det som har sjokkert velgere, kommentatorer, rivaler og internasjonale motparter: Trump skyr tilsynelatende ingen midler. Han ønsker smålighet, urimelighet og ufinhet velkommen, og er så godt som ubeseiret på denne slagmarken. I valgkampen ble rival etter rival dratt ned i søla i møte med Trump $^{3}$. At han, etter nedrige utvekslinger i offentlighetens søkelys, stadig vokste på meningsmålingene, gjorde at han fikk rykte på seg som en teflonkandidat. Sannheten var imidlertid at episodene hjalp Trump. De var ikke belastninger som prellet av, men elementer som understøttet narrativet om at han er en uredd, kompromissløs og sterk leder som vil få det som han vil, koste hva det må.

Interessant nok beskrev Hannah Arendt (1958) nettopp denne dynamikken i boken The Origins of Totalitarianism; det å sjokkere med vulgære og nedverdigende utsagn kan være en hersketeknikk og en maktstrategi som bidrar til å avskrekke motstandere, kapre den politiske debatten og undergrave det bestående, eliten og det «politisk korrekte». Denne bølletilnærmingen bruker Trump også i internasjonal politikk. I tillegg til å måtte forholde seg til et USA som er vesentlig mer knyttet til en person enn tidligere, må internasjonale motparter innfinne seg med at denne

\footnotetext{
${ }^{3}$ Her er nok Florida-senator Marco Rubio det fremste eksemplet (Alme 2016).
} 


\section{Vårin Alme}

personen fører en helt annen stil enn presidenter før ham, og gjerne gjør formell samhandling i internasjonale fora om til noe som ligner munnhoggeri i en skolegård.

\section{G7-møtet}

Disse tre konsekvensene for internasjonal politikk var godt synlige da Trump og lederne i noen av verdens viktigste land møttes i Canada i juni. G7-møtet, som er et forum for USA, Canada, Storbritannia, Frankrike, Italia, Japan og Tyskland, er som regel en formalitet - en gjentatt bekreftelse på enigheten og samarbeidet landene imellom. Årets toppmøte viste imidlertid splittelse og åpen fiendtlighet. Noe av bakgrunnen for dette var uenigheten mellom landene om handel og forsvar, som er blitt tilspisset med Trumps handelstariffer som treffer EU, Mexico og Canada (med ivaretakelse av USAs 'nasjonale sikkerhetsinteresser' som rasjonale), bilateralt press mot Nato-allierte og forsøk på oppsplitting av multilaterale forbund - som oppfordringen til president Emmanuel Macron om å trekke Frankrike ut av EU for å få til en bilateral handelsavtale (Willsher 2018).

Blant de oppsiktsvekkende tingene som skjedde under møtet, kan vi trekke frem at Trump kunngjorde at han ville forlate møtet tidlig for å forberede toppmøtet med Nord-Korea; at Macron, sammen med Canadas statsminister Justin Trudeau, varslet at de ville kritisere Trumps toll på EU-varer under møtet; at Trump etterlyste gjeninkluderingen av Russland i forumet og uttalte at Nato er like ille som handelsavtalen NAFTA - som han har gjort det klinkende klart at han misliker; at Trudeau valgte å starte et møte uten å vente på Trump («stagglers») og senere twitret et bilde som viste Trumps tomme stol; at Trudeau kritiserte Trump, sa seg fornærmet av ham, lovet at canadiere ikke vil la seg herse med og truet med gjengjeldende tariffer mot USA; og at Trump svarte at Trudeaus påstander var falske, kalte ham uærlig og svak og tilbaketrakk USAs støtte til møtets slutterklæring (Borger 2018). Og da gjenstår det å nevne at Trudeau, med en dårlig skjult referanse til Hillary Clintons presidentvalgkamp, twitret ordene «we are stronger together».

Dette hendelsesforløpet illustrerer Trumps påvirkning på internasjonal politikk. For det første synliggjør det hans bilateralisme. At USA kritiserer Nato-allierte som ikke innfrir alliansens krav om å vie $2 \%$ av BNP til forsvar, er ikke nytt. Det er det derimot å utøve slikt hardt bilateralt press mot allierte - og i prosessen, tilsynelatende betinge det som skal være en sikkerhetsgaranti. Denne samme bilateralismen ser vi i ønsket om at Frankrike trekker seg ut av EU til fordel for en bedre bilateral handelsavtale med USA - som tar oss videre til Trumps økonomiske forankring, fokus på forhandling, vinning og absolutte gevinster og sammenblanding av økonomi og sikkerhet. For Trump er EU kun et dårligere økonomisk alternativ til bilaterale handelsavtaler; NAFTA og Nato faller innunder samme kategori, nemlig multilaterale avtaler som muliggjør tapping av USAs ressurser til fordel for ikke-fortjenende land som, når de får lillefingeren, tar hele armen, og det samtidig som de forbeholder seg retten til å kritisere sin velgjører. Her ser vi også hans nasjonalistiske proteksjonisme. En 
overbevisning om at avtaleverkene som har fullbyrdet den liberale verdensordenen egentlig er kynisk utnyttelse av USA, gjør det fullstendig legitimt å kreve mer av disse giddalause allierte.

Ut fra dette kan vi forstå mye, men ikke alt, av Trumps atferd under møtet. For vi har fremdeles ikke nevnt det personlige aspektet. Det er talende at Trump valgte å trekke USA fra slutterklæringen etter det han anså som en personlig fornærmelse fra Trudeau - ikke basert på et skifte i faktisk politikk. For Trump berettiger fornærmelsen ordet «svik», som hans økonomiske rådgiver, Larry Kudlow, også brukte (Tillett 2018). Det nødvendiggjør også et personangrep, som kom i form av en Twitter-melding der Trump omtalte Canadas statsminister ved fornavn.

Dette er en form for diplomati som står uten historisk sidestykke. Hovedgrunnen er at det hele her giøres personlig. Fornærmelser og impulser blir grunnlag for politiske beslutninger. Personlige forhold mellom Trump og andre statsledere - snarere enn de respektive nasjonenes avtaleverk, allianser, forhold og historie - blir det som definerer de to nasjonenes forhold. Dette giør den internasjonale politikken uforutsigbar og spent, i stor grad fordi det blir vanskelig å vurdere om Trump faktisk handler ut fra det han anser som USAs interesse, eller ut fra private, personlige følelser og interesser.

Hvordan håndteres så dette av internasjonale motparter? Blant allierte mottas Trumps fremferd gierne med talende stillhet eller ytterst forsiktig diplomatisk motstand. Konsensusen synes å være at det å sitte stille i båten gir beste mulighet for å ivareta status quo - noe som, gitt alternativet Trump signaliserer, anses som positivt. På noen områder møtes Trump med ettergivenhet og innrømmelser, som strengere innvandringsretorikk eller løfter om økte forsvarsbudsjetter. Men Trump imøtegås også med sin egen medisin. Noen av lederne på G7-møtet viste eksempelvis en, trolig ubevisst, velvilje til å gå i Trumps fotspor ved også selv å personliggiøre politikken de var til stede for å verne om.

Her er det vanskelig ikke å trekke frem Justin Trudeau. Mye sto på spill for Canada under G7-møtet. Opprettholdelsen av handelsavtaler, sikringen av forsvarssamarbeid, den liberale verdensordenens overlevelse - dette er ikke bagateller. Like fullt fremsto Trudeau som om de var nettopp det. For USAs partnere, og særlig Nato-land, er det viktigste av alt i dagens sikkerhetspolitiske situasjon å opprettholde alliansens kollektive forsvar, noe som krever USAs uforbeholdne forpliktelse til Alliansepaktens artikkel fem. For at alliansen skal være effektiv, må den kunne avskrekke potensielle aggressorer, og for at den skal kunne avskrekke, må den fremstå som troverdig. Dette krever det som gjerne kalles cohesion. Mens det finnes reelle politiske uenigheter mellom de sittende regjeringene i USA og Canada, kunne resultatet av toppmøtet ha blitt en forpliktelse til visse viktige ting landene likevel kan enes om. Isteden ble det fiendtlig og personrettet ordveksling, ytterligere steg i retning handelskrig og en slutterklæring uten amerikansk støtte.

Og dette er ikke kun på grunn av Trump. Det er også et resultat av hvordan han imøtegås. Trudeau valgte ikke kun å sette hardt mot hardt i møte med Trump - han 


\section{Vårin Alme}

tydde også til symbolikk og insinuasjoner om en eksistensiell motstand mot Trump. Med andre ord valgte han å møte Trump på slagmarken den amerikanske presidenten er mest komfortabel med. Slik gjorde han feilen også republikanske rivaler begikk i møte med Trump: å opptre som ham - gjøre politikken personlig.

Dette er imidlertid ikke en uunngåelig, ubønnhørlig effekt. Ledere kan velge ikke å gå i denne fellen, og heller følge det som er blitt kjent som høyesterettsdommer Ruth Bader Ginsbergs to leveregler: Det hjelper noen ganger å være litt døv, og en bør alltid sette sin motstanders argument i best mulig lys (Carmon \& Knizhnik 2015). Det siste så vi et vellykket eksempel på da generalsekretær Jens Stoltenberg håndterte Trumps fornærmelser mot Nato med anerkjennelse av validiteten $\mathrm{i}$ presidentens poenger: forsiktig, rasjonell motmæle og ros av presidentens lederskap. Dette var trolig avgjørende for å få Trump til å signere Nato-toppmøtets slutterklæring og sikre enighet der enighet var mulig. Like fullt er Trumps personliggjøring av den internasjonale politikken vanskelig å unngå for hans internasjonale motparter. Og med det følger uforutsigbarhet, forskyvning i relasjoner, forsuring av vennskap og infantilisme.

\section{Konklusjon}

For Donald Trump er alt personlig. Det var med på å gjøre ham til president, og det er den store effekten av hans personlighet på internasjonal politikk. For i møte med Trump har også andre ledere i noen av verdens mektigste land latt seg forlede av denne personliggjøringen. Også for dem er den internasjonale politikken nå personlig, all den tid den handler om å stå imot Donald Trump. Med dette forsvinner skillet mellom det private og det politiske, mellom nasjonal og internasjonal politikk og mellom person og stat. Konsekvensen er et mer spent, infantilt og uforutsigbart internasjonalt klima. Forhåpentligvis slutter årsakskjeden her. Forhåpentligvis vil ikke alle Trumps internasjonale motparter falle for fristelsen til å la det hele bli personlig. En av måtene å sikre dette på, er kanskje noen ganger å være litt døv.

\section{Om forfateren}

Vårin Alme er utdannet statsviter og jobber for nettstedet AmerikanskPolitikk. no. Her er hun kommentator, redaksjonsmedlem og en av stemmene i podkasten AMPOLCAST. Hun kommenterer og skriver også jevnlig for ulike mediehus. Under presidentvalget i 2016 og mellomvalget i 2018 var hun en av TV 2s kommentatorer.

\section{Litteratur}

Alme,Vårin (2016). Rubios retoriske helomvending - begynnelsen på slutten. AmerikanskPolitikk. Tilgjengelig på: https:/www.amerikanskpolitikk.no/2016/03/11/rubios-retoriske-helomvending-begynnelsen-pa-slutten/ Lest: 12.06.18.

Alme, Vårin (2017a), Hvordan blir USAs 45. president? NRK Ytring. Tilgjengelig på: https://www.nrk.no/ ytring/hvordan-blir-usas-45.-president_-1.13307144 Lest: 26.06.18. 


\section{Når alt blir personlig. Trump i internasjonal politikk}

Alme, Vårin (2017b). For syns skyld. AmerikanskPolitikk. Tilgjengelig på: http://www.amerikanskpolitikk. no/2017/01/31/for-syns-skyld/ Lest: 19.05.18.

Alme, Vårin (2017c). Trump modererer valgkampløftene. NRK Ytring. Tilgjengelig på: https://www.nrk.no/ ytring/trump-modererer-valgkamploftene-1.13535949 Lest: 19.05.18

Applebaum, Anne (2013). Putinism: The Ideology. Philippe Roman Chair in History and International Affairs 2012-13 LSE IDEAS. Tilgjengelig på: http://www.lse.ac.uk/ideas/Assets/Documents/updates/LSE-IDEASPutinism-The-Ideology.pdf Lest: 13.06.18.

Arendt, Hannah (1958). The Origins of Totalitarianism. Cleveland: The World Publishing Company.

Borger, Julian (2018). Trump Trashed Nato at G7, Calling it 'As Bad as Nafta', Officials Confirm. Tilgjengelig på: https://www.theguardian.com/us-news/2018/jun/28/trump-nato-latest-news-as-bad-as-nafta-g7-summit Lest: 04.07.18.

Carmon, Irin \& Knizhnik, Shana (2015). Notorious RBG: The Life and Times of Ruth Bader Ginsberg. New York: Dey Street Books.

Collins, Eliza (2016). Trump: I consult myself on Foreign Policy. Politico https://www.politico.com/blogs/2016gop-primary-live-updates-and-results/2016/03/trump-foreign-policy-adviser-220853

Comey, James (2018). A Higher Loyalty: Truth, Lies, and Leadership. New York: Flatiron Books.

Hill, Fiona \& Gaddy, Clifford G. (2013). Mr. Putin. Operative in the Kremlin. Washington D.C.: Brookings Institution Press.

Lockie, Alex (2018). Trump says he showed 'good instincts' by firing Comey before he had found any wrongdoing. LA Times. Tilgjengelig på: https://nordic.businessinsider.com/trump-unloads-on-comey-fbiafter-ig-finds-serious-lapses-in-judgment-2018-6/ Lest: 26.06.18.

McCarthy, Tom (2017). Trump voters see his flaws, but stand by president who 'shakes things up'. The Guardian. Tilgjengelig på: https:/www.theguardian.com/us-news/2017/dec/24/trump-voters-see-his-flaws-but-standby-president-who-shakes-things-up Lest: 18.10.18.

Meet the Press (2015). Meet the Press Transcript - August 16, 2015. NBC News. Tilgjengelig på: https://www. nbcnews.com/meet-the-press/meet-press-transcript-august-16-2015-n412636 Lest: 01.06.18.

Mitchell, Andrea (2018). Trump relies on gut instinct. The North Koreans have 45 years of preparation. NBC News. Tilgjengelig på: https://www.nbcnews.com/news/world/trump-relies-gut-instinct-north-koreanshave-45-years-preparation-n881596 Lest: 04.07.18.

Nazaryan, Alexander (2017). Trump on Fox News, Asserts Own Power: «I'm the Only One that Matters». Newsweek. Tilgjengelig på: http://www.newsweek.com/laura-ingraham-interview-fox-news-donald-trump700608 Lest: 04.07.18.

Restad, Hilde Eliassen (2017). Det amerikanske valget (Eller: Er enden nær?), Internasjonal Politikk. 75 (1): 5-12.

Romarheim, Anders G. (2017). USA og Norge i Trumps verden. Internasjonal Politikk. 75 (1): 36-44.

Steinhovden, Thor (2018). Det amerikanske marerittet - hvordan USA ble et splittet land. Oslo: Res Publica.

Stone, Jon (2017). Donald Trump's daughter Ivanka 'fills in for him at G20 world leaders meeting'. Independent. Tilgjengelig på: https:/www.independent.co.uk/news/donald-trump-ivanka-trump-g20-fill-in-a7830431. html Lest: 18.10.18.

Tillett, Emily (2018). Larry Kudlow: Trudeau «betrayed» Trump at G7, «should have known better». CBS News. Tilgjengelig på: https:/www.cbsnews.com/news/larry-kudlow-on-face-the-nation-canadian-pm-justintrudeau-betrayed-trump-at-g7-should-have-known-better/ Lest: 05.07.18.

Willsher, Kim (2018). Quit the EU for a Better Trade Deal, Trump Reportedly Told Macron. The Guardian. Tilgjengelig på https:/www.theguardian.com/business/2018/jun/29/quit-eu-bilateral-trade-deal-trumptold-macron-us-france-terms Lest: 05.07.18.

Woodward, Bob (2018). Fear: Trump in the White House. New York: Simon \& Schuster.

Zito, Salena (2016). Taking Trump Seriously, Not Literally. The Atlantic. Tilgjengelig på: https://www. theatlantic.com/politics/archive/2016/09/trump-makes-his-case-in-pittsburgh/501335/ Lest: 12.07.18. 